\title{
New Daily Persistent Headache
}

National Cancer Institute

\section{Source}

National Cancer Institute. New Daily Persistent Headache. NCI Thesaurus. Code

C117082.

A bilateral, unremitting headache of mild to moderate intensity that occurs daily and may be associated with photophobia, phonophobia, or mild nausea. 